\title{
RANCANG BANGUN INTEGRASI TOMBOL EKSPOSI DENGAN LAMPU TANDA RADIASI DAN PENGUNCI PINTU OTOMATIS
}

\author{
${ }^{1}$ Ali Amroji, ${ }^{2}$ Ismanto, ${ }^{3}$ Novia Legita Maharani \\ ${ }^{1,2,3}$ ATRO Nusantara \\ Coresponding Author: Ismanto \\ Email: ismanto@atronusantara-jakarta.ac.id
}

\begin{abstract}
Background: Generally the use of radiation sign lamp in radiology department hospitals at Jabodetabek area is still manual by pressing button the switch on or off, also the door is opened when the radiation sign lamp are on, although there is no x-ray examination in the room. This often becomes ambiguousby the public. This study aims to minimize ambiguous in order to improve radiation safety by build a miniature automatic integration system with an exposure button with a radiation sign lamp and automatic door lock for indicator radiation safety on a radiology department hospital.

Method: This study uses an experimental research method, by build hardware on a miniature that resembles a radiology examination room, then tested the usage function with 3 radiographers as respondents by providing a function test form and the results processes using the formula average.

Results: Respondents' answers with an average result of 3.6 showed that this miniature design was successful / able to illustrate the efforts of radiation safety and radiation protection by means of automatic work that was able to minimize the ambiguous of people's understanding of radiation signaling lamps and radiological doors.
\end{abstract}

Keywords: integration, lamp, door lock, radiation, radiology

\section{Pendahuluan}

Radiologi merupakan sarana penunjang di rumah sakit yang memanfaatkan radiasi pengion. sinar- $\mathrm{X}$ adalah radiasi pengion yang disamping bermanfaat juga dapat menimbulkan gangguan kesehatan bagi pasien, pekerja radiasi maupun masyarakat sekitar. Maka, pelayanan radiologi harus memperhatikan aspek keselamatan radiasi (N. Fairusiyyah, B. Widjasena, And E. Ekawati, 2016)

Menurut Peraturan Pemerintah nomor 29 tahun 2008, tentang Perizinan Pemanfaatan Sumber Radiasi Pengion Dan Bahan Nuklir menyebutkan bahwa program proteksi radiasi adalah tindakan sistematis dan terencana untuk melindungi pekerja, pasien dan masyarakat sekitar dari bahaya radiasi, serta memastikan ketersediaan dan kelayakan perlengkapan proteksi radiasi, dan memantau pemakaiannya, berpartisipasi dalam mendesain fasilitas radiologi, memberikan proteksi terhadap pasien, dirinya sendiri, dan masyarakat di sekitar ruang pesawat $\mathrm{X}$-ray, menerapkan prosedur yang tepat untuk meminimalkan pajanan yang diterima pasien sesuai kebutuhan (Hiswara, 2015).

Lampu tanda radiasi merupakan salah satu syarat dari fasilitas pesawat sinar-x guna untuk keselamatan radiasi di rumah sakit yang ditujukan untuk masyarakat sekitar yang berada di wilayah instalasi radiologi (Mustafa,2012). Sehingga adanya lampu tanda radiasi merupakan hal yang sangat penting di instalasi radiologi.

Umumnya sekarang ini lampu indikator radiasi di instalasi radiologi rumah sakit Jabodetabek masih menggunakan sistem manual untuk menyalakannya dan lampu tersebut tidak informatif menandakan apakah didalam ruangan sedang dilakukan pemeriksaan atau tidak, keadaannya pintu juga tidak terkuncisehingga siapapun bebas keluar masuk ruang radiologi, hal ini dapat 
membahayakan orang tersebut. Idealnya lampu tersebut menyala saat ada pemeriksaan dan lampu mati saat tidak ada pemeriksaan didalam ruangan, sehingga lampu benar-benar akurat menandakan bahwa di dalam ruang radiologi sedang ada atau tidak ada pemeriksaan.

Padazaman yang serba otomatis ini, penulis terdorong untuk membuat rancang bangun integrasi tombol eksposi dengan lampu tanda radiasi dan pengunci pintu otomatis bertujuan saat tombol esposi ditekan (radiasi keluar), lampu tanda radiasi menyala dan pintu terkunci. Sehingga apabila ada masyarakat sekitar yang ingin masuk ruang radiologi saat pemeriksaan sedang berlangsung, pintu tidak akan terbuka karena terkunci otomatis, dan akhirnya orang yang ingin masuk tadi tidak terpapar radiasi. Hal ini merupakan upaya proteksi radiasi.

\section{Metode}

Rancangan penelitian ini adalah Rancang Bangun/pembuatan alat, yang kemudian dilakukan uji fungsi kepada radiographer di rumah sakit wilayah Jakarta, lalu mengisi kuisioner skala likert (sugiono, 2012), setelah didemokan alat, hasil ujinya diolah secara kuantitatif cross sectional, menggunakan rumus rata-rata, kemudian dihitung dengan Skor Kriterium. Responden adalah 3 radiografer rumah sakit di Jakarta. Penelitian ini dilakukan pada bulan Maret-April 2019.

\section{Hasil dan Pembahasan}

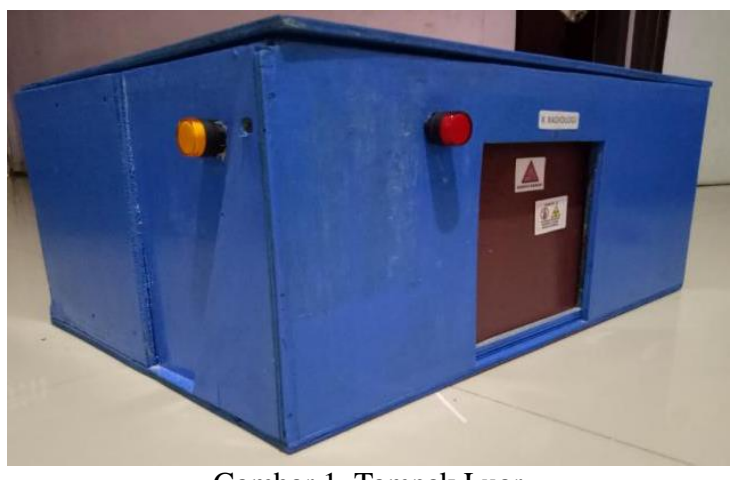

Gambar 1. Tampak Luar

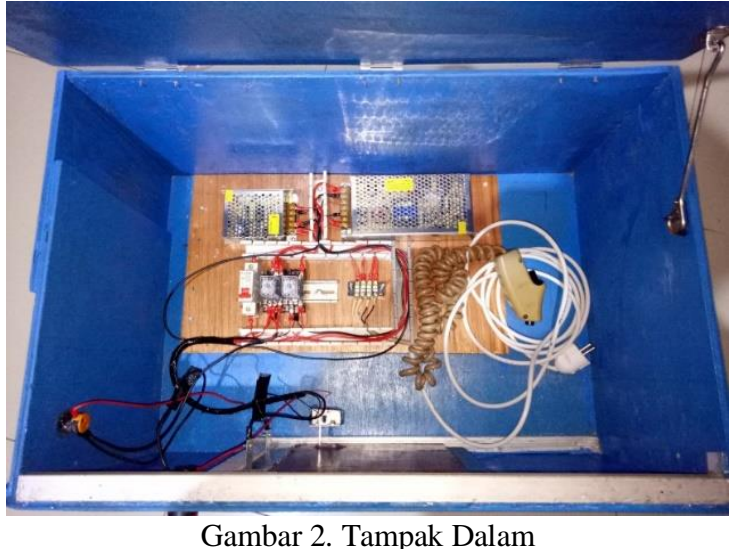

Cara kerja integrasi tombol eksposi dengan lampu tanda radiasi dan sistem pengunci otomatis :

1. Steker dihubungkan pada stop kontak yang teraliri oleh listrik PLN.

2. MCB di on kan.

3. Miniature pintu tertutup rapat.

4. Tekan tombol ready pada hand switch X-ray.

5. Lampu indikator merah dan solenoid lock akan teraliri listrik, ditandai dengan menyalanya lampu indikator merah dan terkuncinya pintu oleh solenoid lock.

6. Tekan tombol X-ray pada hand switch.

7. Lampu indikator kuning (tanda X-ray keluar) akan teraliri listrik, ditandai dengan menyalanya lampu indikator kuning (lampu indikator merah dan solenoid lock masih menyala).

8. Lepas tombol pada hand switch X-ray (ready dan ekspos).

9. Lampu indikator merah, kuning dan solonoid lock sudah tidak teraliri listrik, ditandai dengan matinya kedua lampu indikator dan tidak terkuncinya pintu.

Tabel 1. Hasil Rata-rata Kuisioner

\begin{tabular}{|l|l|c|c|c|c|c|c|}
\hline \multirow{2}{*}{ No } & \multirow{2}{*}{ Pertanyaan } & \multirow{2}{*}{ Responden } & \multicolumn{4}{|c|}{ Penilaian } & \multirow{X}{*}{} \\
\cline { 4 - 7 } & & & A & B & C & D & \\
\hline 1. & $\begin{array}{l}\text { Bagaimana } \\
\text { tingkat } \\
\text { keselamatan } \\
\text { radiasi } \\
\text { apabila rancang } \\
\text { bangun } \\
\text { ini dapat } \\
\text { direalisasikan }\end{array}$ & 3 & 2 & 1 & & & 3,6 \\
\hline
\end{tabular}




\begin{tabular}{|l|l|l|l|l|l|l|l|}
\hline 2. & $\begin{array}{l}\text { Bagaimanakah } \\
\text { kelayakan } \\
\text { rancang ini } \\
\text { bangun ini } \\
\text { apabila dapat } \\
\text { direalisasikan }\end{array}$ & 3 & 2 & 1 & & & 3,6 \\
\hline 3. & $\begin{array}{l}\text { Bagaimanakah } \\
\text { tingkat } \\
\text { keberhasilan } \\
\text { rancang } \\
\text { bangun ini }\end{array}$ & 3 & 2 & 1 & & & 3,6 \\
\hline
\end{tabular}

terkunci dan saat tombol ditekan (ready dan X-ray). Saat tombol eksposi (ready) ditekan maka solonid lock dan lampu indikator merah ( lampu tanda radiasi) akan teraliri listrik sehingga lampu indikator merah (lampu tanda radiasi) akan menyala dan solenoid lock akan mengunci pintu. Kemudian saat tombol eksposi (Xray) ditekan maka solenoid lock, lampu indikator merah (lampu tanda radiasi), lampu indikator kuning (lampu tanda $\mathrm{X}$ -

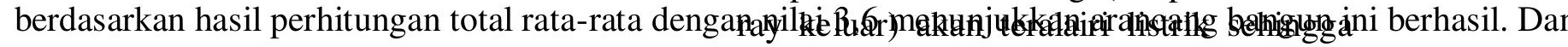
lampu indikator merah tetap menyala, lampu indikator kuning baru menyala, dan solenoid lock tetap mengunci pintu.

\section{Keselamatan Radiasi}

Keselamatan radiasi adalah bagian dari keselamatan secara keseluruhan. Terminologi keselamatan radiasi dan proteksi radiasi sering digunakan secara bersamaan. Proteksi radiasi berhubungan dengan pembatasan dosis radiasi sedangkan keselamatan radiasi berhubungan dengan mengurangi potensi kecelakaan radiasi.

Program proteksi dan keselamatan radiasi adalah tindakan sistematis dan terencana untuk melindungi pekerja, anggota masyarakat dan lingkungan hidup dari bahaya radiasi.

Lampu indikator merah pada ruamgan radiologi atau yang lebih sering disebut lampu tanda radiasi merupakan salah satu syarat keselamatan radiasi atau upaya dariproteksi radias di rumah sakit yang ditujukan untuk orang-orang yang berada di wilayah instalasi radiologi. Sehingga adanya lampu tanda radiasi merupakan hal yang sangat penting di instalasi radiologi. (Perka BAPETEN Nomor 8, 2011).

\section{Kelayakan Rancang Bangun}

\section{a. Tombol Eksposi}

Pengujian tombol eksposi dinyatakan berhasil dilakukan saat tombol eksposi ditekan dengan keadaan pintu yang tertutup rapat untuk menentukan keakuratan fungsi masing-masing dari tombol eksposi (ready dan X-ray) yang dapat bekerja dengan benar saat pintu b. Lampu Indikator Merah (Lampu Tanda Radiasi)

Pengujian lampu tanda radiasi dinyatakan berhasil dilakukan saat tombol eksposi (ready dan X-ray) ditekan dan pintu dalam keadaan tertutup rapat untuk menentukan lampu benar-benar menyala di waktu yang tepat yaitu pada saat radiasi akan keluar, radiasi keluar dan saat pintu tertutup rapat dengan benar.

\section{c. Pengunci pintu (solenoid lock)}

Pengujian sistem pengunci pintu (solenoid lock) dilakukan saat pintu dipastikan tertutup rapat, dan pada saat tombol eksposi (ready dan X-ray) ditekan. Untuk menentukan sistem pengunci benarbenar mengunci diwaktu yang tepat yaitu pada saat radiasi akan keluar, radiasi keluar dan pintu tertutup rapat.

\section{Tingkat Keberhasilan Rancang Bangun}

Berdasarkan hasil kuisioner yang telah diisi oleh berapa responden dengan hasil rata-rata 3,6 menunjukkan bahwa rancang bangun ini berhasil. Dengan hasil rata-rata 3,6 menunjukan tingkat keberhasilan rancang bangun ini sangat baik.

\section{Simpulan}

Secara garis besar, berdasarkan hasil dan pembahasan dapat disimpulkan sebagai berikut: 
1. Miniature Rancang bangun ini mampu mengilustrasikan upaya proteksi dan keselamatan radiasi dengan cara kerja nya yang otomatis sehingga meminimalkan terjadinya kesalahan yang menyebabkan menurunnya kualitas keselamatan radiasi dan proteksi radiasi.

2. Berdasarkan hasil kuisioner yang telah diisi oleh berapa responden dengan hasil rata-rata 3,6 menunjukkan bahwa rancang bangun ini berhasil.

Saran

Pengembangan rancang bangun ini diharapkan dapat direalisasikan dalam bentuk nyata di rumah sakit atau dipesawat rontgen langsung.

\section{Daftar Pustaka}

Hiswara, Eri.Buku Pintar Proteksi Dan Keselamatan Radiasi Di Rumah Sakit, Batan Press, 2015

Mustafa, Ahmad. Kondisi Ruangan Radiografi Gigi Pada Instalasi Kesehatan Di Kota Makassar. Diss. 2012.

N. Fairusiyyah, B. Widjasena, And E. Ekawati, "Analisis Implementasi Manajemen Keselamatan Radiasi Sinar-X Di Unit Kerja Radiologi Rumah Sakit Nasional Diponegoro Semarang Tahun 2016," Jurnal Kesehatan Masyarakat (E-Journal), Vol. 4, No. 3, Pp. 514-527, Aug. 2016. 